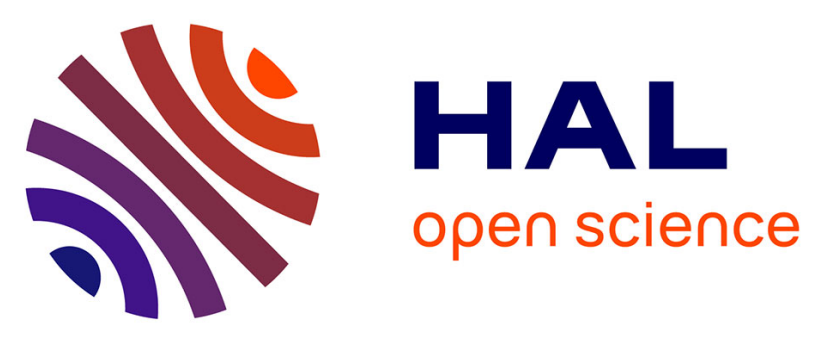

\title{
Investigations of surface layer temperature and morphology of hard machinable materials used in aircraft industry during abrasive electrodischarge grinding process
}

M. Goląbczak, R. Święcik, A. Goląbczak, Corinne Nouveau, Philippe Jacquet, C. Blanc

\section{To cite this version:}

M. Goląbczak, R. Święcik, A. Goląbczak, Corinne Nouveau, Philippe Jacquet, et al.. Investigations of surface layer temperature and morphology of hard machinable materials used in aircraft industry during abrasive electrodischarge grinding process. Materials Science and Engineering Technology / Materialwissenschaft und Werkstofftechnik, 2018, 49 (5), pp.568-576. 10.1002/mawe.201700249 . hal-03080403

\section{HAL Id: hal-03080403 https://hal.science/hal-03080403}

Submitted on 17 Dec 2020

HAL is a multi-disciplinary open access archive for the deposit and dissemination of scientific research documents, whether they are published or not. The documents may come from teaching and research institutions in France or abroad, or from public or private research centers.
L'archive ouverte pluridisciplinaire HAL, est destinée au dépôt et à la diffusion de documents scientifiques de niveau recherche, publiés ou non, émanant des établissements d'enseignement et de recherche français ou étrangers, des laboratoires publics ou privés. 


\title{
Investigations of surface layer temperature and morphology of hard machinable materials used in aircraft industry during abrasive electrodischarge grinding process
}

\section{Untersuchungen zur Oberflächentemperatur und zur Morphologie von schwer zerspanbaren Werkstoffen, die in der Luftfahrtindustrie beim abtragenden elektrolytischen Entladungsschleifen eingesetzt werden}

\begin{abstract}
M. Gołąbczak ${ }^{1}$, R. Święcik ${ }^{1}$, A. Gołąbczak ${ }^{2}$, C. Nouveau ${ }^{3}$, P. Jacquet ${ }^{4}$, C. Blanc ${ }^{4}$

In this work the results related to the influence of selected electrical parameters of the abrasive electrodischarge grinding process on the surface layer temperature and morphology of machined samples in comparison to the conventional grinding method are presented. The basis of this work has been investigation of the deep grinding of surfaces of the samples made of titanium $5553 \beta$, Inconel 617 , Hastelloy $X$ and magnesium AZ31 using a cubic boron nitride (CBN) grinding wheel with metallic binding agent. For the comparative evaluation of the conventional grinding and abrasive electrodischarge grinding, measurements of the specific grinding energy, temperature on the surface layer (at the contact of the grinding wheel-workpiece) and geometric structure of the surface layer have been used.
\end{abstract}

Keywords: Abrasive electrodischarge grinding / grinding temperature / energy consumption / surface morphology / hard machinable materials

In dieser Arbeit werden die Ergebnisse vorgestellt, die sich auf den Einfluss ausgewählter elektrischer Parameter des Abrasivelektrodispergierens auf die Oberflächenschichttemperatur und Morphologie von bearbeiteten Proben im Vergleich zur konventionellen Schleifmethode beziehen. Die Grundlage dieser Arbeit war die Untersuchung des Tiefenschliffs von Oberflächen der Proben aus Titan $5553 \beta$, Inconel 617, Hastelloy X und Magnesium AZ31 mit einer kubisch kristallinen Bornitrid (CBN) Schleifscheibe mit metallischem Bindemittel. Für die vergleichende Bewertung des konventionellen Schleifens und des Abrasivelektrodispergierens wurden Messungen der spezifischen Schleifenergie, der Temperatur auf der Oberflächen-

1 Lodz University of Technology, Stefanowskiego 1/15 Street, 90-924 LODZ, POLAND

2 Higher Vocational State School in Wloclawek, 3 Maja 17 Street, 87-800 WLOCLAWEK, POLAND

3 Arts et Métiers Paris Tech, Rue Porte de Paris, 71250 CLUNY, FRANCE

4 École Catholique des Arts et Métiers, 40 Montée Saint-Barthélémy, 69321 LYON, FRANCE

Corresponding author: M. Gołąbczak, Lodz University of Technology, Stefanowskiego 1/15 Street, 90-924 LODZ, POLAND,

E-Mail: marcin.golabczak@p.lodz.pl 
schicht (beim Kontakt des Schleifscheiben-Werkstücks) und der geometrischen

Struktur der Oberflächenschicht verwendet.

\section{Schlüsselwörter: Abrasivelektrodispergierendes Schleifen / Schleiftemperatur / Energieverbrauch / Oberflächenmorphologie / schwer zerspanbare Materialien}

\section{Introduction}

Abrasive electrodischarge grinding (AEDG) is a hybrid process of machining where synergy of mechanical energy and electric spark discharges are observed. The mechanism of removal of machining allowance in abrasive electrodischarge grinding is a result of the synergy of spark discharges taking place between the metal bond of the grinding wheel and the surface layer of the machining workpiece and the machining of abrasive grains of the cutting surface of the grinding wheel (CSGW). Available publications and our own articles indicate that hybrid methods of machining, including abrasive electrodischarge grinding, are the most suitable for solving all the problems appearing in processes of working hard machinable construction materials, including alloys used in the aircraft industry [1-8]. Involvement of different forms of energy in the process of reduction machining allowances increases machining efficiency and quality of machined surfa- ces. In the abrasive electrodischarge grinding process problems appear concerning the influence of electric spark discharge energy which causes additional heat flux. It has a significant influence on the outer layer of machined workpieces [5, 8-10]. In this article the investigation results concerning estimation of the conditions of the abrasive electrodischarge grinding process on the temperature of the surface layer, the degree of energy intensity of grinding process and roughness and morphology of machined aerospace alloys like magnesium AZ31, Hastelloy X, Inconel 617 and titanium $5553 \mathrm{~B}$ are presented. The AZ31 magnesium alloy is characterized by very low density $\left(1.8 \mathrm{~g} / \mathrm{cm}^{3}\right)$, has very low hardness $(70 \mathrm{HB})$ and tensile strength (350 MPa). The melting point of AZ31 magnesium alloy is only $600{ }^{\circ} \mathrm{C}$. Magnesium alloys are used where weight reduction is necessary, i.e. in motorization and aeronautics. The titanium 5553 beta alloy has higher density $\left(4.6 \mathrm{~g} / \mathrm{cm}^{3}\right)$ and hardness $(370 \mathrm{HB})$ and has extremely high tensile strength $(1350 \mathrm{MPa})$. The melt-
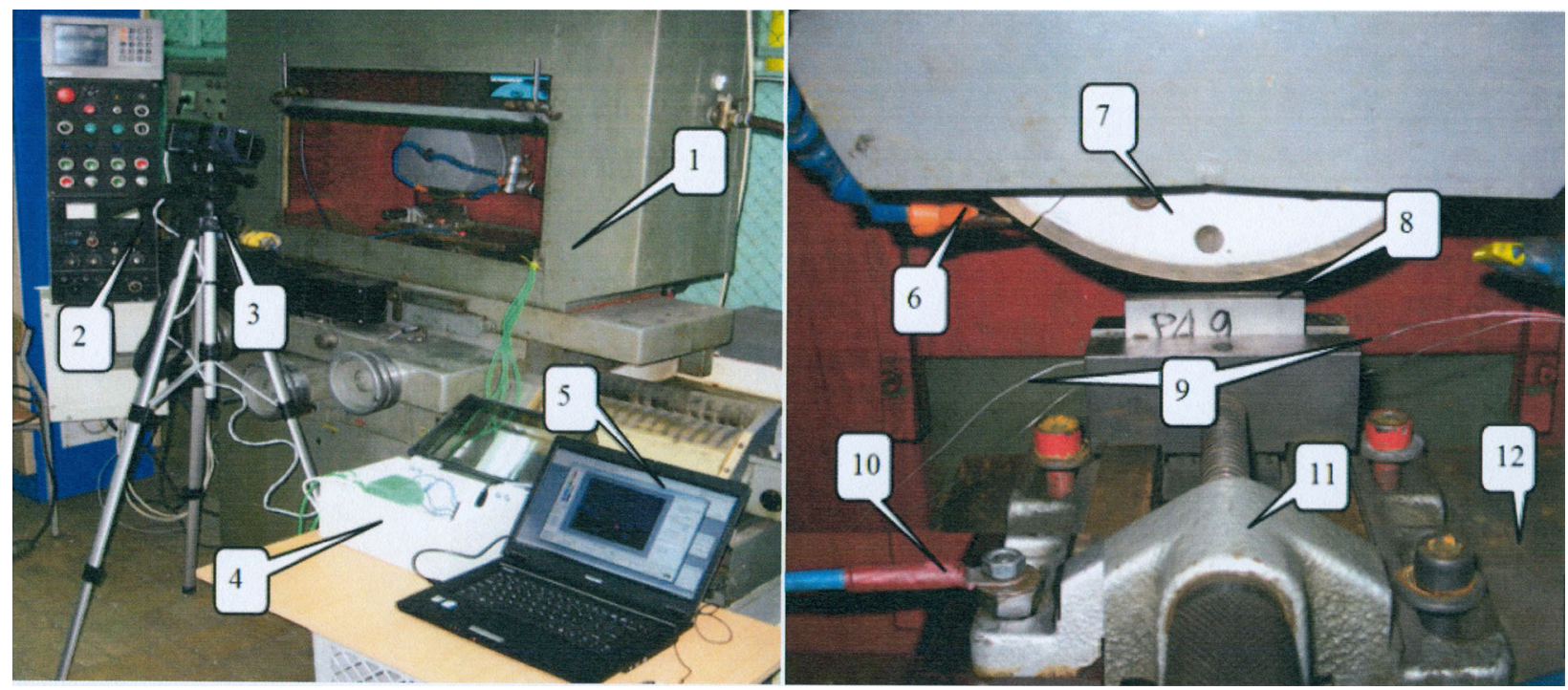

Figure 1. Work-stand: 1) ECBT8 grinder, 2) control panel, 3) thermo vision camera, 4) temperature amplifiers, 5) personal computer, 6) dielectric feed pipe, 7) grinding wheel, 8) grinding plate, 9) thermocouple, 10) feeder cable from the generator of electric pulses, 11) vice, 12) table.

Bild 1. Arbeitstisch: 1) ECKT8 Schleifer, 2) Bedienfeld, 3) Wärmebildkamera, 4) Temperaturverstärker, 5) Computer, 6) dielektrische Zuleitung, 7) Schleifscheibe, 8) Schleifteller, 9) Thermoelement, 10) Zuleitung vom Generator der elektrischen Impulse, 11) Schraubstock, 12) Tisch. 
ing point of titanium beta alloy is also very high, at $1670{ }^{\circ} \mathrm{C}$. Titanium alloys are used in production of many parts of planes and medical implants. Nickel alloys like Inconel 617 and Hastelloy $\mathrm{X}$ have very high density $\left(8.2 \mathrm{~g} / \mathrm{cm}^{3}\right)$ and hardness $(300 \mathrm{HB})$ and have high tensile strength (700 MPa). The melting point of nickel alloys is very high (up to $2000{ }^{\circ} \mathrm{C}$ ). They are used in the production of blades for turbines. The range of investigations has covered tests of abrasive electrodischarge grinding of these alloys in different conditions of electrical parameters of impulse generator and comparatively tests of conventional grinding using dielectric coolant and without it (dry grinding).

\section{Work-stand, method and grinding conditions}

Abrasive electrodischarge grinding tests have been conducted at the experimental site equipped with the surface grinding machine ECBT8 and impulse discharge generator of the GMP75 type. The test site, presented in our earlier papers has been equip- ped with control and measurement circuits for grinding parameters, three-axial piezoelectric force gauge 9257B made by KISTLER and a computerized system for experimental data storage $[5,6$, 8]. For the recording of the working current intensity and voltage drop during discharge a special measurement kit has been elaborated, which consists of ECBT8 grinder, generator of electric pulses, thermo vision camera, temperature amplifiers and a personal computer, Figure 1.

Across the machined workpiece made of different kind of aerospace alloys, four thermocouples have been mounted in the blind holes, Figure 2. The measurements of the grinding temperature have been carried out using a thermocouple of type $\mathrm{K}$, plugged into the temperature transducers LMPT-21ME, from which the measurement signal is transmitted to the measurement card PCI-6132 (National Instruments-USA). Recorded results of temperature have been transmitted via USB to the computer. For communication between computer and the recording unit the LabVIEW2015 software was used. The scope of the investigations include tests of the deep abrasive electrodischarge grinding of the planar samples made

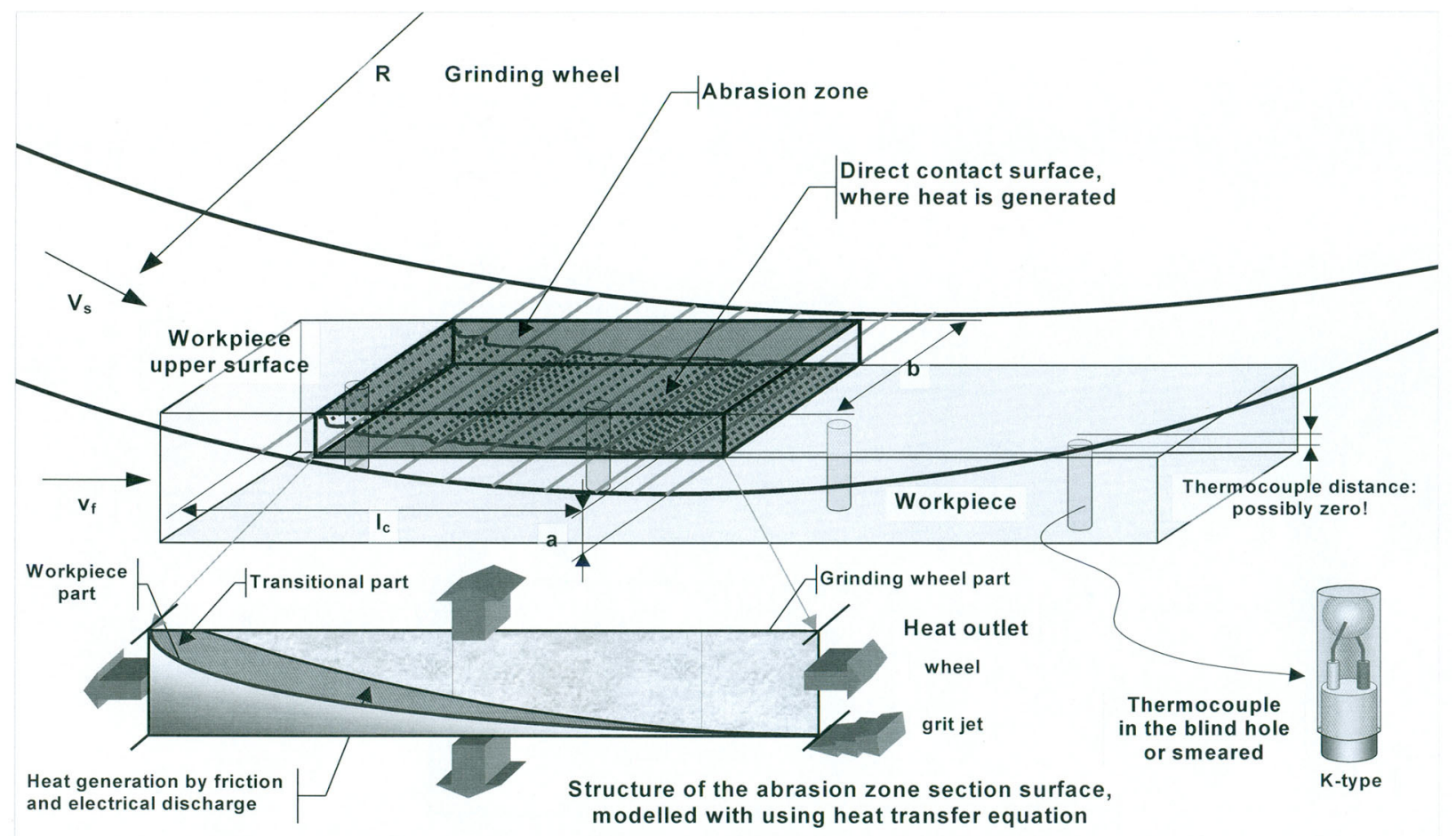

Figure 2. Grinding temperature measurement scheme and thermocouple placement in the ground sample.

Bild 2. Schleiftemperaturmessschema und Thermoelementplatzierung in der Probe. 
of titanium $5553 \beta$, Inconel 617 , Hastelloy $X$ and magnesium AZ31 (dimensions $40 \mathrm{~mm} \times 20 \mathrm{~mm}$ $\times 10 \mathrm{~mm}$ ) using a grinding wheel made of regular boron nitride with a metallic binding agent (CBN $125 / 100 \mathrm{M} 75)$. In the grinding tests performed, the temperature distributions have been recorded, Figure 2. They have allowed for an estimation of the maximal temperature of the surface layer of investigated alloys. For the quantitative evaluation of the grinding processes the specific energy of grinding of hard machinable materials has been used. Consumption of energy of the abrasive electrodischarge grinding process (limited to the participation of conventional grinding in the whole process) has been evaluated from the tangential component of force and speed of grinding:

$e_{s}=\frac{E_{C G}}{V_{m}}=\frac{F_{t}}{V_{m}} v_{s}\left[\mathrm{~J} / \mathrm{mm}^{3}\right]$

where: $e_{\mathrm{S}}-$ specific energy of grinding, $E_{\mathrm{CG}}-$ energy of conventional grinding, $F_{\mathrm{t}}$ - tangential component of grinding force, $v_{\mathrm{s}}$ - speed of grinding wheel, $V_{m}$ - volume of grinding material.

\section{Experimental conditions}

Experimental investigations comprised machining tests of the titanium $5553 \beta$, Inconel 617, Hastelloy $\mathrm{X}$ and magnesium AZ31 alloys using abrasive elec- trodischarge grinding and conventional grinding process for comparison in selected conditions, $\mathrm{Ta}$ ble 1. The range of investigations has covered the determination of the influence of the:

- Electric discharge power on the specific energy of grinding,

- electric discharge power on temperature in surface layer,

- electric discharge power on geometric structure surface and morphology.

\subsection{Influence of the electric discharge power on specific energy of abrasive electrodischarge grinding}

The basis of estimation of energy intensity $e_{\mathrm{S}}$ have been measurements of the tangential component of the grinding force $F_{\mathrm{t}}$ and volume of grinding material $V_{m}$. Investigation results have concerned influence of generator power of spark discharge on the tangential component of grinding force of the selected aerospace alloys during abrasive electrodischarge grinding and conventional grinding (CG), Table 2. Tests of abrasive electrodischarge grinding have been realized in conditions of positive polarization of electrodes, i.e. the positive pole $(+)$ from the impulse generator has been connected to grinding samples made of aerospace alloys. Obtained values have concerned the average tangential component of the grinding force from three grinding

Table 1. Parameters of grinding.

Tabelle 1. Parameter des Schleifens.

\begin{tabular}{|c|c|c|c|}
\hline \multicolumn{2}{|l|}{$\begin{array}{l}\text { Conditions of AEDG process } \\
\text { Kinematical parameters }\end{array}$} & \multicolumn{2}{|l|}{ Electrical parameters } \\
\hline Speed of grinding $v_{s}[\mathrm{~m} / \mathrm{s}]$ & 30 & Working voltage $U[\mathrm{~V}]$ & $100-200$ \\
\hline Feed of grinding wheel $a[\mu \mathrm{m}]$ & 20 & Working current $I[\mathrm{~A}]$ & $8-25$ \\
\hline Speed of table feed $v_{f}[\mathrm{~m} / \mathrm{min}]$ & 0.5 & $\begin{array}{l}\text { Impulse duration time } t_{\text {on }}[\mu \mathrm{s}] \\
\text { Impulse break time } t_{\text {off }}[\mu \mathrm{s}]\end{array}$ & $\begin{array}{l}32 \\
63\end{array}$ \\
\hline \multicolumn{4}{|l|}{ Tests of grinding } \\
\hline Test symbol & \multicolumn{2}{|c|}{ Type of grinding } & Electrical parameters of generator \\
\hline P1 & \multicolumn{2}{|c|}{ Conventional grinding (dry grinding) } & - \\
\hline P2 & \multicolumn{2}{|c|}{ Conventional grinding with coolant } & - \\
\hline P3 & \multicolumn{2}{|c|}{ AEDG } & $U=100 \mathrm{~V}, I=8 \mathrm{~A}$ \\
\hline P4 & \multicolumn{2}{|c|}{ AEDG } & $U=150 \mathrm{~V}, I=12 \mathrm{~A}$ \\
\hline P5 & \multicolumn{2}{|c|}{ AEDG } & $U=200 \mathrm{~V}, I=25 \mathrm{~A}$ \\
\hline \multicolumn{4}{|c|}{ Technical characteristic of grinding wheel: CBN 125/100 M75 } \\
\hline
\end{tabular}


Table 2. Influence of the electric discharge power on tangential component of grinding force.

Tabelle 2. Einfluss der elektrischen Entladungskraft auf die tangentiale Komponente der Schleifkraft.

\begin{tabular}{lllll}
\hline & \multicolumn{2}{l}{ Tangential component of grinding force $F_{\mathrm{t}}[\mathrm{N} / \mathrm{mm}]$} & \\
Process type & Titanium $5553 \beta$ & Inconel 617 & Hastelloy X & Magnesium AZ31 \\
\hline $\begin{array}{l}\text { P1 } \\
\text { (CG dryly) }\end{array}$ & 3.31 & 6.66 & 4.60 & 2.66 \\
P2 & 2.42 & 2.17 & 3.20 & 0.64 \\
$\begin{array}{l}\text { (CG with coolant) } \\
\text { P3 }\end{array}$ & 2.44 & 2.20 & 3.24 & 0.33 \\
AEDG $(U=100 \mathrm{~V}, I=8 \mathrm{~A})$ & 1.73 & 1.73 & 2.03 & 0.24 \\
P4 & & & \\
AEDG $(U=150 \mathrm{~V}, I=12 \mathrm{~A})$ & 1.10 & 0.97 & 1.14 & 0.16 \\
P5 & & &
\end{tabular}

tests, Table 2. Based on the measured average tangential components of the grinding force it has been possible to determine (according to Equation 1) the specific energy of the abrasive electrodischarge grinding process limited to the participation of conventional grinding in the whole process, Figure 3. Presented investigation results have confirmed the significant influence of abrasive electrodischarge grinding on the decrease of specific energy of grinding comparing to conventional grinding. Significant decrease of specific energy of grinding has been obtained in conditions of the abrasive electrodischarge

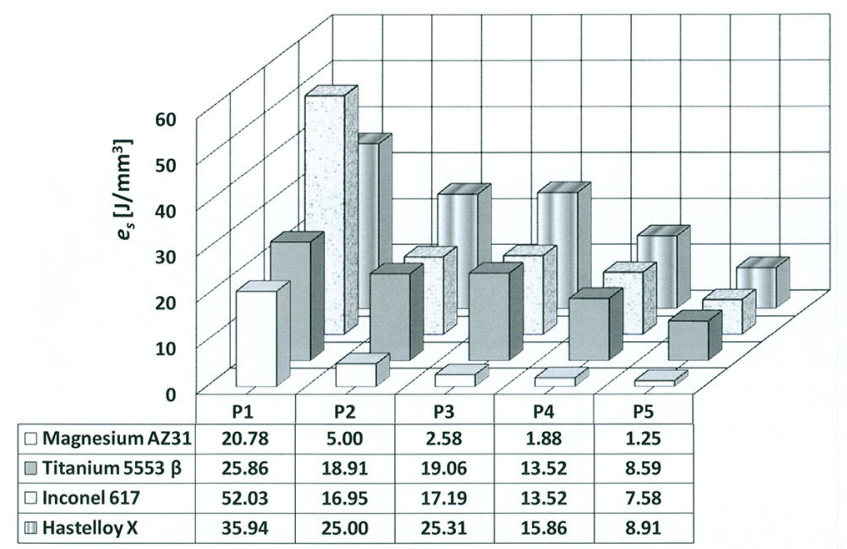

Figure 3. Effect of electric discharge power on specific energy after conventional grinding and AEDG processes of hard machinable materials used in aircraft industry.

Bild 3. Auswirkung der elektrischen Entladungsleistung auf die spezifische Energie nach konventionellem Schleifen und AEDG-Verfahren von schwer zerspanbaren Materialien, die in der Flugzeugindustrie verwendet werden. grinding process with average (P4) and high (P5) values of power of electrical discharge generator. Percentage decrease of the specific energy of grinding during abrasive electrodischarge grinding compared to conventional grinding with coolant (P2) has been respectively equal to: For titanium $5553 \beta$ about $30 \%$ - 55\%, for Inconel 617 about $20 \%$ $55 \%$, for Hastelloy X about $35 \%-65 \%$ and for magnesium AZ31 about $60 \%-75 \%$. Decrease of specific energy of grinding has confirmed at the same time a significant participation of the energy of the electric spark discharge in removal of machining allowance. Investigation results haven't depicted significant differences in values of specific energy of grinding for Inconel 617, Hastelloy X and titanium $5553 \beta$ in conditions of low power of electrical discharge generator (P3) when compared to conventional grinding (P2). It means that in conditions of usage of low electrical parameters of generator, electric spark discharge energy is too small for melting of hard machinable aerospace alloys. Total machining allowance in the abrasive electrodischarge grinding process has been removed by the mechanical energy of machining by abrasive grains. Different results have been obtained during the abrasive electrodischarge grinding process of the magnesium AZ31 alloy for which the lowest specific energy of grinding has been observed. It has been also ascertained that under low electrical discharge generator conditions (P3) a significant decrease of specific energy of grinding by about $50 \%$ has been obtained, when compared to conventional grinding (P2). It means that electric spark discharge energy 
has been sufficient for melting of the low fusible magnesium AZ31 alloy (about $650{ }^{\circ} \mathrm{C}$ ) and has had significant share in removal of machining allowance. Obtained results have also confirmed that earlier observations of authors presented in works [36 , where it has been proven that along with the increase of power of the electric impulse generator (increase of voltage and intensity of electric current) there is a decrease in the specific energy of grinding of the abrasive electrodischarge grinding process which testifies to the increase of the effectiveness of the spark erosion process in reducing machining allowance. One can expect that the efficiency of the

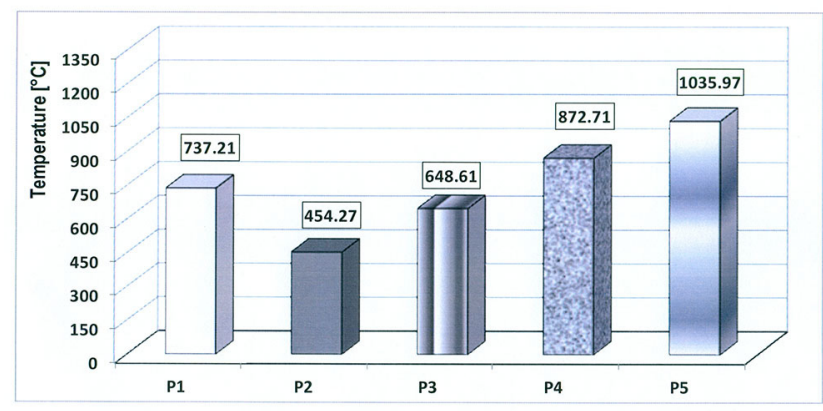

Figure 4. Comparison of experimental results of the temperature profile of the surface layer in the conventional grinding and AEDG process using a CBN grinding wheel for Inconel 617.

Bild 4. Vergleich der experimentellen Ergebnisse des Temperaturprofils der Oberflächenschicht beim konventionellen Schleifen und AEDG-Verfahren unter Verwendung einer CBN-Schleifscheibe für Inconel 617.

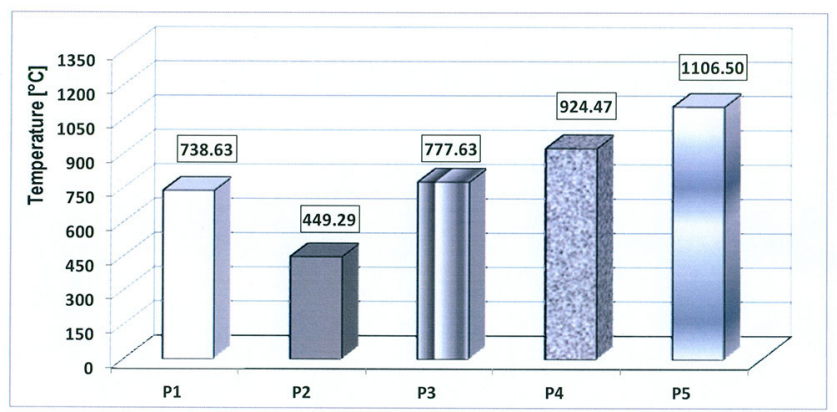

Figure 5. Comparison of experimental results of the temperature profile of the surface layer in the conventional grinding and AEDG process using a CBN grinding wheel for Hastelloy $\mathrm{X}$.

Bild 5. Vergleich der experimentellen Ergebnisse des Temperaturprofils der Oberflächenschicht beim konventionellen Schleifen und AEDG-Verfahren unter Verwendung einer CBN-Schleifscheibe für Hastelloy $X$. abrasive electrodischarge grinding process depends on the melting temperature of the machining alloys.

\subsection{Influence of the electric discharge power on temperature in surface layer}

Investigations have involved estimating the influence of the abrasive electrodischarge grinding conditions on the maximal grinding temperature of the surface layer of selected aircraft alloys: Hastelloy X, Inconel 617 and titanium 5553 B and magnesium AZ31. The range of realized investigations has included: Tests of conventional grinding without coolant (P1) and with dielectric coolant (P2) and tests of abrasive electrodischarge grinding in variable conditions of electrical parameters of impulse generator (tests P3-P5), Figures 4-7. The average values of maximal temperatures have been elaborated basing on measurements from four thermocouples and three test repeats. The analysis of results obtained in tests of conventional grinding without coolant (P1) and with dielectric coolant (P2) have shown that values of maximal temperature of surface layer of respective alloys can be ranged in the following order: Titanium $5553 \beta$ (836.09 ${ }^{\circ} \mathrm{C}$ - dryly and $527.38{ }^{\circ} \mathrm{C}$ - with coolant), Hastelloy X $\left(738.63{ }^{\circ} \mathrm{C}\right.$ - dryly and $449.29^{\circ} \mathrm{C}$ with coolant), Inconel $617\left(733.21{ }^{\circ} \mathrm{C}\right.$ - dryly and $454.27{ }^{\circ} \mathrm{C}$ - with coolant), magnesium AZ31 $\left(516.89{ }^{\circ} \mathrm{C}\right.$ - dryly and $262.57{ }^{\circ} \mathrm{C}$ - with coolant).

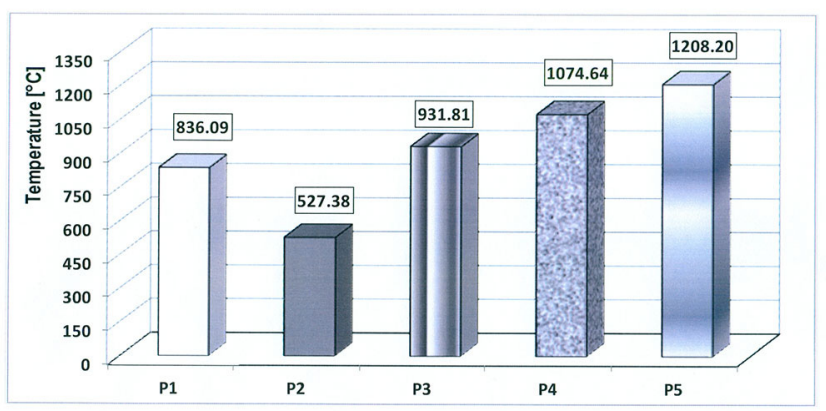

Figure 6. Comparison of experimental results of the temperature profile of the surface layer in the conventional grinding and $A E D G$ process using a CBN grinding wheel for titanium $5553 \beta$ alloy.

Bild 6. Vergleich der experimentellen Ergebnisse des Temperaturprofils der Oberflächenschicht beim konventionellen Schleifen und AEDG-Verfahren unter Verwendung einer CBN-Schleifscheibe für Titan $5553 \beta$-Legierung. 


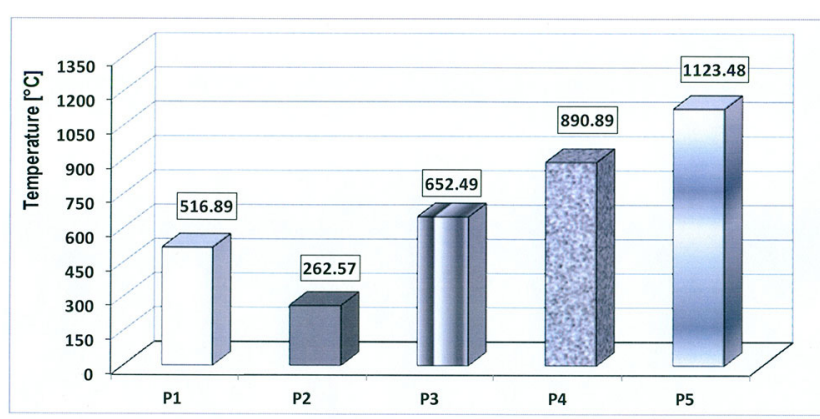

Figure 7. Comparison of experimental results of the temperature profile of the surface layer in the conventional grinding and AEDG process using a CBN grinding wheel for magnesium AZ31 alloy.

Bild 7. Vergleich der experimentellen Ergebnisse des Temperaturprofils der Oberflächenschicht beim konventionellen Schleifen und AEDG-Verfahren unter Verwendung einer CBN-Schleifscheibe für eine Magnesium AZ31-Legierung.

Abrasive electrodischarge grinding tests (P3-P5) have confirmed a significant increase in the grinding temperature of the surface layer of aircraft alloys like Hastelloy X, Inconel 617, titanium 5553 ß and magnesium AZ31, comparing to conventional grinding $(\mathrm{P} 2)$. It has also been proven that the increase of power of the electric impulse generator (increase of voltage and intensity of electric current) has had strong influence on increase of the maximal grinding temperature of surface layer of aircraft alloys. Out of grinded aircraft alloys the highest values of maximal grinding temperature has been obtained in abrasive electrodischarge grinding of titanium $5553 \beta$, amounted to $931^{\circ} \mathrm{C}-1208{ }^{\circ} \mathrm{C}$. The percentage increase of the maximal grinding temperature of surface layer in respective abrasive electrodischarge grinding tests, comparing to conventional grinding (P2), has amounted to: $45 \%$ for low values of power of generator (P3), $51 \%$ for average values of power of generator (P4) and $57 \%$ for high values of power of generator (P5). The values of maximal grinding temperature of surface layer of the rest aircraft alloys during the abrasive electrodischarge grinding process have been lower and amounted respectively: $772{ }^{\circ} \mathrm{C}-1106{ }^{\circ} \mathrm{C}$ for Hastelloy $\mathrm{X}, 648^{\circ} \mathrm{C}-1106{ }^{\circ} \mathrm{C}$ for Inconel 617 and $652{ }^{\circ} \mathrm{C}-1123{ }^{\circ} \mathrm{C}$ for magnesium AZ31. Percentage increase of maximal grinding temperature of surface layer in respective abrasive electrodischarge grinding tests, comparing to conventional grinding $(\mathrm{P} 2)$, has amounted to: $42 \%-60 \%$ for Hastelloy X,
$30 \%-66 \%$ for Inconel 617 and $60 \%-77 \%$ for magnesium AZ31. Significant increase of the maximal grinding temperature of the surface layer of aircraft alloys during abrasive electrodischarge grinding process when compared to conventional grinding $(\mathrm{P} 2)$ is a consequence of the influence of the additional energy flux from electric spark discharge in this process. Due to the unfavourable effect of the influence of this flux on properties of the surface layer of grinded aircraft alloys it is purposeful to continue further research in this field. The research should investigate the modeling of the temperature distribution in the surface layer in the abrasive electrodischarge grinding process and assessment of internal stresses in surface layer [5-7].

\subsection{Assessment of geometrical structure of surface layer of aircraft alloys after abrasive electrodischarge grinding process}

Presented investigation results have concerned assessment of stereometric surface parameters (SGP) and morphology of the surface layer of selected aircraft alloys like: Magnesium AZ31, Hastelloy X, Inconel 617 and titanium 5553 B after abrasive electrodischarge grinding process realized in conditions of test P4, Figures 8-9. Analysis of obtained results shows significant changes in the shape of the sur-

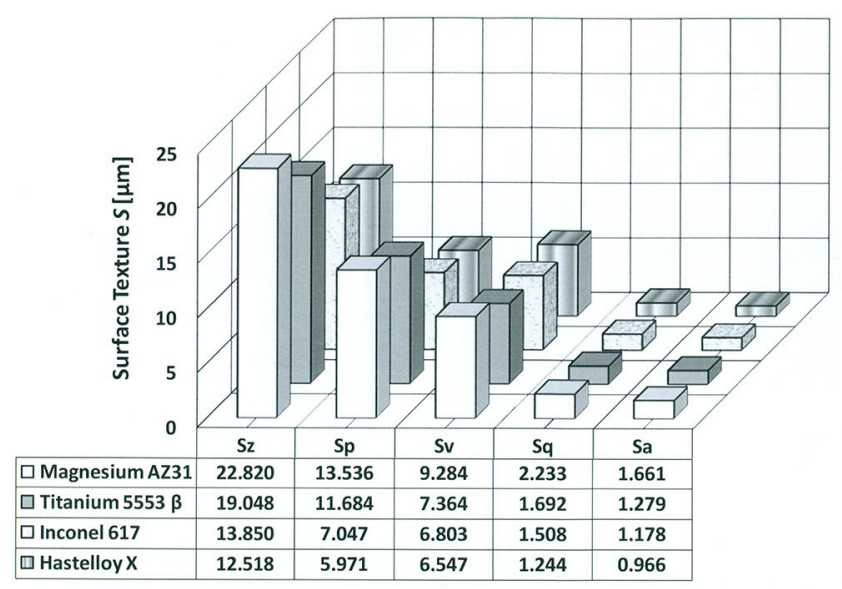

Figure 8. Comparison of stereometric surface parameters of samples made of aircraft alloys after AEDG process in conditions of test $\mathrm{P} 4$.

Bild 8. Vergleich der stereometrischen Oberflächenparameter von Proben aus Flugzeuglegierungen nach AEDG-Verfahren unter Testbedingungen P4. 


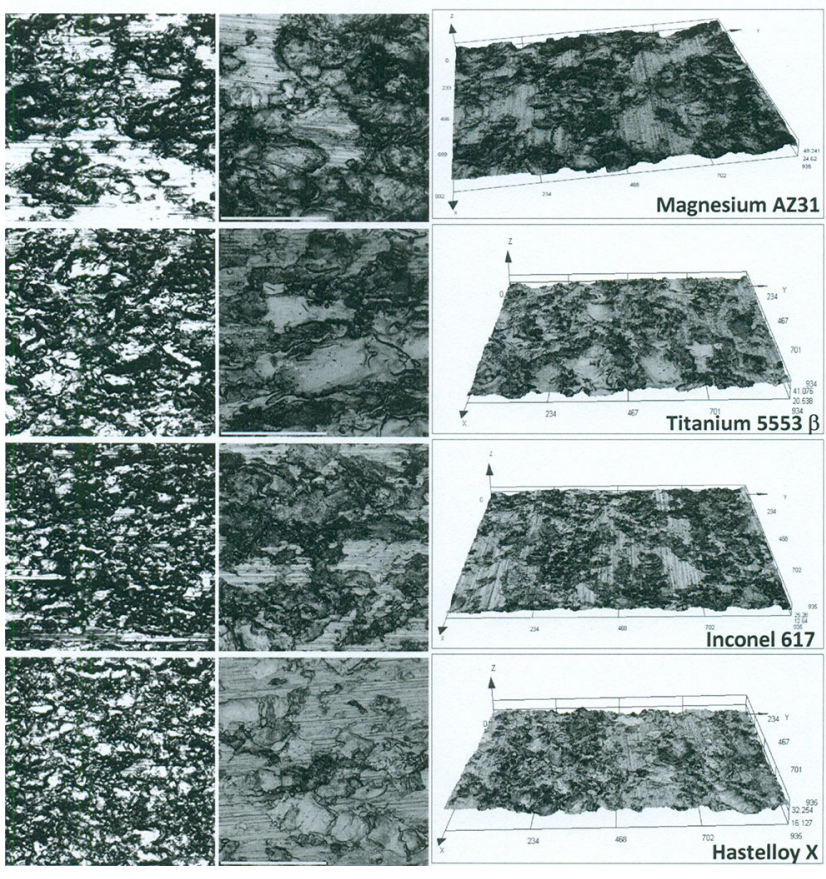

Figure 9. Microstructure images of aircraft alloys after AEDG in conditions of test P4 (in 2D and 3D configuration).

Bild 9. Mikrostrukturbilder von Flugzeuglegierungen nach dem AEDG unter Testbedingungen P4 (in 2D- und 3D-Konfiguration).

face geometrical structure of samples made of aircraft alloys after abrasive electrodischarge grinding process. An important observation is the fact that under the same conditions of the abrasive electrodischarge grinding process the best stereometric surface parameters have been obtained for nickel alloys like Hastelloy X $\left(S_{a}=0.966 \mu \mathrm{m}, S_{k u}=3.675, S_{s k}=\right.$ $0.056)$ and Inconel $617\left(S_{a}=1.176 \mu \mathrm{m}, S_{k u}=3.654\right.$, $\left.S_{s k}=0.110\right)$ compared to titanium 5553 beta alloy $\left(S_{a}=1.279 \mu \mathrm{m}, S_{k u}=4.544, S_{s k}=0.372\right)$ and magnesium AZ31 alloy $\left(S_{a}=1.661 \mu \mathrm{m}, S_{k u}=4.844\right.$, $S_{s k}=0.286$ ). For assessment of morphology of aircraft alloys in 2D and 3D configuration the Olympus BX $51 \mathrm{M}$ optical microscope (ENSAM, Cluny) and Olympus DSX-HRSU optical profiling system (ECAM, Lyon) have been used, Figure 9. Microstructure images of all grinded samples have revealed the presence of micro craters and weld penetrations caused by electric spark discharges, which are characteristic for the electrical discharge machining (EDM) processes. It should be emphasized that hybrid abrasive electrodischarge machining (in conditions of test P4) increases efficiency of removing the machining allowance and increases grinding wheel life when compared to conventional grinding. Unfavorable phenomena resulting from the abrasive electrodischarge grinding process are however revealed on the surface layer of sample micro craters and weld penetrations caused by heat flux from electric spark discharges [5,6]. They impair surface roughness and have bad effect on the stereometric surface parameters as a consequence of the influence of additional heat flux from electric spark discharges. The depth of micro craters and weld penetrations depend on the power of the electric impulse generator. A limitation of these unfavorable phenomena can be done by optimization of electrical parameters of the abrasive electrodischarge grinding process (tension and intensity of electric current, impulse duration time) and application of additional final machining (e.g. polishing).

\section{Conclusions}

The investigations carried out have enabled the estimation of electrical conditions of the abrasive electrodischarge grinding process of aircraft alloys on the specific energy of grinding, maximal grinding temperature of surface layer, morphology and stereometric surface parameters. Investigation results of the abrasive electrodischarge grinding process have confirmed that an increase of the power of the electric impulse generator (increase of voltage and intensity of electric current) has an influence on the decrease of the specific energy of grinding and increase share of energy of electric spark discharge in this process and increases the maximal grinding temperature of surface layer. Morphology of surface layers of samples after the abrasive electrodischarge grinding have shown presence of micro craters and weld penetrations caused by electric spark discharges. The depth of these micro craters depends on generator power and spark discharges. Having regard to assessment of tribological properties of surface layer it is purposeful to continue further research into the abrasive electrodischarge grinding process of hard machinable aircraft alloys. Further investigations should concern optimization of electrical parameters of generator, modeling and experimental investigations of the specific energy of grinding in the abrasive electrodischarge grinding process, evaluation of the distribution of temperature in the surface layer and state of stresses in the surface layer of grinded alloys. 


\section{References}

[1] E.O. Ezugwu, Z.M. Wang, J. Mater. Process. Technol. 1997, 68, 262.

[2] P. Govindan, V.V. Praveen, Int. J. Eng. Sci. Res. Technol. 2014, 4, 1932.

[3] S.K.S. Yadav, V. Yadava, V.L. Narayana, Int. J. Adv. Manuf. Tech. 2008, 36, 34.

[4] J. Kozak, M. Zybura-Skrabalak, G. Skrabalak, Procedia CIRP 2016, 42, 872.

[5] A. Gołąbczak, R. Święcik, Machine Eng. 2009, 12, 19.

[6] M. Gołąbczak, A. Gołąbczak, A. Konstantynowicz, Materialwiss. Werkstofftech. 2017, 48, 335.
[7] M. Gołąbczak, A. Gołąbczak, A. Konstantynowicz, R. Święcik, Continuum Mech. Thermodyn. 2016, 28, 1.

[8] A. Gołąbczak, A, Konstantynowicz, M. Gołąbczak, Defect Diffus. Forum 2016, 367, 25.

[9] M. Duscha, F. Klocke, A. d'Entremont, B Linke, H. Wegner, Proc. Manuf. Syst. 2010, 5, 143.

[10] V.K. Jain, R.G. Mote, Int, J. Adv. Manuf. Tech. 2005, 26, 56.

Received in final form: December $11^{\text {th }} 2017$ 